ISSN: 0854-4220

SAWERIGADING

JURNAL BAHASA DAN SASTRA

VOLUME 24, NO. 2, DESEMBER 2018

KONSTRUKSI IDEOLOGIS DALAM WACANA BULETIN AL ISLAM: SEBUAH TINJAUAN ANALISIS WACANA KRITIS (Ideological Construction in Discourse of Al Islam Bulletin: A Critical Discourse Analysis Review) MOH. ZALHAIRI, SUMARLAM, DWI PURNANTO

ANALISIS NARATIF BERITA KONFLIK KPK DAN POLRI DI MEDIA INDONESIA ONLINE (Narrative Analysis concerning Conflict News between Corruption Eradication Commission (KPK) and Indonesian National Police (Polri) in Media Indonesia Online)

$143-155$

\title{
SRI WAHYUNI
}

CERITA RAKYAT LAKIPADADA: NEGOSIASI KEABADIAN DAN KENISBIAN DALAM PERSPEKTIF HEIDEGGER (Folkore of Lakipadada: Negotiations of Eternity and Relativity in Heidegger Perspective)

EVA YENITA SYAM

$157-164$

KONSEP MASKULIN DALAM KARYA METROPOP ANTOLOGI RASA KARYA IKA NATASSA (Masculine Concept in Popular Literature Novel Antologi Rasa by Ika Natassa)

DIAH MEUTIA HARUM

METAFORA KONSEPTUAL DALAM LIRIK LAGU BAND REVOLVERHELD ALBUM IN FARBE (Conceptual Metaphor in Songs Lyric Revolverheld Band Album in Farbe)

TRYTA DESSILIONA ${ }^{1}$, TAJUDIN NUR ${ }^{21}$

TRADISI MERANTAU DALAM “LELAKI DAN TANGKAI SAPU” (Tradition of Wandering in "Lelaki dan Tangkai Sapu”)

MARLINA

HABITUS DAN MODAL DAENG KANDURUAN ARDIWINATA DI ARENA KESUSASTRAAN SUNDA MODERN (Habitus and Capital of Daeng Kanduruan Ardiwinata in Modern Sundanese Literature Arena)

PENGUASAAN BUDAYA INDONESIA DALAM TULISAN IMAJINATIF (STUDI KASUS SISWA DI SACRED HEART GIRLS COLLEGE, AUSTRALIA) Mastering Indonesian Culture in Imaginative Writing (Student Case Study in the Sacred Heart Girls College, Australia) 